\title{
Pengembangan Modul Pembelajaran Bangun RuangDengan Metode Creative Problem Solving (CPS) Pada Siswa Kelas VIII SMP
}

\author{
${ }^{1}$ Nutia Rahmatin, ${ }^{2}$ Dewi Pramita, ${ }^{3}$ Sirajuddin, ${ }^{4}$ Mahsup \\ 1,2,3,4 Pendidikan Matematika, FKIP Universitas Muhammadiyah Mataram, Indonesia \\ 1nuthya.rahmatin@gmail.com, ${ }^{2}$ mitha dhewi@yahoo.com, ${ }^{3}$ sirajuddin.ekhy@yahoo.com, ${ }^{4}$ supyeka@gmail.com
}

\section{INFO ARTIKEL}

\section{Riwayat Artikel:}

Diterima:10-03-2019

Disetujui:20-04-2019

\section{Kata Kunci:}

Modul, Model Four-D, Creative Problem Solving (CPS), Bangun Ruang

\section{Keywords:}

Modul, Four-D Model, Creative Problem Solving (CPS), Building Space

\begin{abstract}
ABSTRAK
Abstrak: Bahan ajar yang digunakan oleh guru di SMP Negeri 3 Mataram dalam pembelajaran matematika adalah buku siswa dan LKS (Lembar Kerja Siswa). Pembelajaran matematika yang mendorong kemampuan pemecahan masalah masih kurang dan belum dapat dikembangkan. Oleh sebab itu, perlu adanya pengembangan bahan ajar modul matematika dengan menggunakan metode CPS merupakan suatu solusi yang tepat untuk membantu siswa dan guru dalam pembelajaran matematika yang bertujuan untukmeningkatkan kemampuan siswa dalam bentuk kreative dan dalam memecahkan masalah. Penelitian ini bertujuan untuk menghasilkan Modul Pembelajaran Dengan Metode CPS Pokok Bahasan Bangun Ruang Pada Siswa Kelas VIII SMP. Selain itu, penelitian ini juga dilakukan untuk mengetahui kualitas kelayakan LKS yang dihasilkan berdasarkan aspek kevalidan, kepraktisan, dan keefektian. Jenis penelitian ini adalah penelitian pengembangan modul dengan model pengembangan yang digunakan dalam penelitian ini adalah 4-D (Define, Design, Develop, and Disemination) yang dikembangkan oleh Thiagarajan, Semmel dan Semmel. Hasil penelitian ini menunjukkan kualitas produk yang dihasilkan berdasarkan (1) aspek kevalidan memenuhi kriteria valid dengan rata-rata total penilaian validator adalah 3,92. (2) Aspek kepraktisan memenuhi kriteria praktis dengan rata-rata total nilai siswa81,8 dan angket respon siswa dengan persentase sebesar $100 \%$ dan (3) aspek keefektifan memenuhi kriteria efektif dengan ketuntasan klasikal hasil belajar siswa yaitu $100 \%$.
\end{abstract}

\begin{abstract}
The teaching materials used by teachers in SMP Negeri 3 Mataram in mathematics learning are student books and LKS (Student Worksheets). Mathematical learning that encourages problem solving skills is still lacking and cannot be developed. Therefore, the need for the development of mathematics module teaching materials using the CPS method is an appropriate solution to help students and teachers in mathematics learning that aims to improve students' abilities in creative form and in solving problems. This study aims to produce a Learning Problem Model with CPS Subjects in Building Space in Class VIII. In addition, this study was also conducted to determine the quality of the LKS feasibility based on the aspects of validity, practicality and effectiveness. This type of research is module development research with the development model used in this study is 4-D (Define, Design, Develop, and Disemination) developed by Thiangarajan, Semmel and Semmel. The results of this study indicate that the quality of the products based on (1) the validity aspect meets the valid criteria with the average of the total validator assessment is 3.92. (2) Practical aspects meet the practical criteria with an average total score of 81.8 students and student response questionnaires with a percentage of $100 \%$ and (3) effectiveness aspects meet the effective criteria with classical completeness of student learning outcomes that is $100 \%$.
\end{abstract}

\section{A. LATAR BELAKANG}

Pendidikan merupakan upaya manusia untuk memperluas pengetahuan dalam rangka membentuk nilai, sikap, dan perilaku. Pendidikan juga merupakan salah satu sarana untuk mengembangkan potensi diri dan keterampilan siswa melalui proses pembelajaran sebagai bekal bagi dirinya menjalani hidup bermasyarakat, berbangsa dan bernegara. 
Sebagaimana dalam Undang-undang No. 20 Tahun 2003 tentang Sistem Pendidikan Nasional pasal 1 ayat 1 (2003: 2) secara tegas menyatakan bahwa: "Pendidikan merupakan usaha sadar dan terencana untuk mewujudkan suasana belajar dan prosespembelajaran agar siswa secara aktif mengembangkan potensi dirinya untuk memiliki kekuatan spiritual keagamaan, pengendalian diri, kepribadian, kecerdasan, akhlak mulia, serta keterampilan yang diperlukan dirinya, masyarakat, bangsa dan negara."

Matematika merupakan salah satu pelajaran yang sangat penting untukdiajarkan dalam setiap jenjang satuanpendidikan karena menjadi dasar bagi perkembangan ilmu yang lain. Salah satu kompetensi yang harus dimiliki siswa dalam belajar matematika adalah memahami konsep matematika seperti pada salah satu butir dalam Permendiknas Nomor 22 Tahun 2006 (Depdiknas, 2006). Salah satu sumber belajar yang dapat digunakan untuk memahami konsep materi adalah modul. Modul merupakan salah satu bahan ajar yang disajikan secara sistematis. Pengertian modul adalah bahan ajar yang disusun secara sistematis dan menarik yang mencakup isi materi, metode, dan evaluasi yang dapat digunakan secara mandiri (Prastowo, 2011:108).

Berdasarkan hasil observasi peneliti di sekolah SMPN 3 Mataram sampai saat ini masih menggunakan buku paket dan LKS kecuali bahan ajar yang berupa bahan cetak seperti modul belum pernah digunakan. Bahan ajar cetak yang masih digunakan tersebut hanya berisi ringkasan materi, contoh soal dan latihan-latihan soal dalam pembelajara matematika. Strategi pengorganisasian dan penyampaian isi di dalam bahan ajar cetak tersebut banyak yang bersifat abstrak dan rumit sehingga siswa enggan untuk membacanya apalagi mempelajarinya. Hal itu dipengaruhi oleh pembelajaran yang digunakan pada saat proses belajar mengajar masih menerapkan pembelajaran konvensional. Dimana guru menjadi pusat perhatian sedangkan siswa hanya duduk mendengarkan penjelasan dari guru. Hal itu yang menyebabkan pembelajaran matematika tidak tercapai. Oleh sebab itu, diperlukan pembelajaran yang inovatif, pembelajaran yang dimaksud yaitu pembelajaran Creative Problem Solving(CPS) yang merupakan variasi dari pembelajaran problem solving dengan pemecahan masalah melalui teknis sistematis dalam mengorganisasikan gagasan kreatif untuk menyelesaikan masalah.Creative Problem Solving(CPS) adalah suatu proses, metode, atau sistem untuk mendekati suatu masalah di dalam suatu jalan imaginatif dan menghasilkan tindakan efektif.

Metode CPSadalah suatu metode pembelajaran yang menekankan pada kerja kelompok yang memusatkan pada pembelajaran dan keterampilan
(Uno, 2011:223). Ketika dihadapkan dengan suatu pertanyaan, siswa dapat melakukan keterampilan memecahkan masalah untuk memilih dan mengembangkan tanggapan. Siswa menggunakan segenap pemikiran memilih strategi pemecahannya, dan memproses hingga menemukan penyelesaian dari suatu masalah.

Terdapat empat langkah dalam metodeCPS dalam pembelajaran matematika pertama, klarifikasi masalah meliputi pemberian penjelasan kepada siswa tentang masalah yang diajukan agar siswa dapat memahami tentang penyelesaiannya yang diharapkan. kedua, pengungkapan masalah, siswa dibebaskan untuk mengungkapkan gagasan tentang berbagai macam strategi penyelesaian masalah. ketiga, Evaluasi dan seleksi, setiap kelompok pendapat-pendapat dan strategi atau strategi-strategi yang cocok untuk menyelesaikan masalah. keempat, implementasi, siswa menentukan strategi yang dapat diambil untuk menyelesaikan masalah. Keempat langkah ini akan membawa siswa menemukan berbagai alternatif solusi dalam memecahkan suatu masalah. Berbagai alternatif solusi yang tepat dalam memecahkan masalah yang disajikan (Zainab, 2013:35) . Proses pencarian alternatif solusi sangat membutuhkan kreatifitas siswa, sehingga dalam metode CPSini kreatifitas siswa terasah.

\section{B. METODE PENELITIAN}

\section{Rancangan Penelitian}

Model penelitian ini adalah Research and Development (R \& D). Menurut Sugiyono (2016: 297) penelitian dan pengembangan adalah metode penelitian yang digunakan untuk menghasilkan produk tertentu, dan menguji keefektifan produk tersebut.Sedangkan menurut Emzir (2014: 263) penelitian dan pengembangan

merupakanpenelitianyangmengembangkan produkproduk tertentu untuk mengetahui kebutuhankebutuhan tertentu denganspesifikasi yang detail. Jadi penelitian pengembanganmerupakan metode untuk menghasilkan produk tertentuatau menyempurnakan produk yang telah ada serta menguji keefektifan produk tersebut.

Jenis produk yang dihasilkan dalam pengembangan ini adalah bahan ajar berupa modul. Produk yang dihasilkan ini akan diuji kelayakannya terlebih dahulu. Untuk menguji layak atau tidaknya, awalnya modul ini akan divalidasi terlebih dahulu untuk melihat kevalidan dan kepraktisannya. Model pengembangan modulyang digunakan dalam penelitian ini adalah 4-D (Define, Design, Develop, and Disemination) yang dikembangkan oleh Thiangarajan, Semmel dan Semmel.Penggunaan model 4-D dalam penelitian ini karena model ini sampai pada tahap penyebaran produk.Penyebaran produk tersebut merupakan salah satu tujuan dari penelitian ini yakni produk yang dihasilkan mampu membantu siswa 
dalam meningkatkan kemampuan pemecahan masalah.

\section{Subjek Penelitian}

Subjek uji coba dilakukan pada siswa kelas VIII $_{\mathrm{a}}$ uji coba terbatas danVIII $\mathrm{b}_{\mathrm{b}}$ uj lapangan SMPN 3 Mataram. Pemilihan kelas ini ditentukan oleh guru pamong disekolah karena cukup mengetahui kemampuan dan karakter siswanya di masingmasing kelas.

\section{Instrumen Penelitian}

Penelitian ini menggunakan instrumen pengumpulan data berupa angket mengenai kelayakan modul matematika guna dalam meningkatkan kemampuan siswa dalam memecahkan masalah.Angket ini disusun berdasarkan kriteria-kriteria yang terdapat dalam modul yang sudah dibuat. Adapun angket pada penelitian ini berupa: (a) lembar angket tim ahli, (b) angket uji coba /Respon Siswa dan (c) Soal Tes hasil evaluasi belajar.

\section{Teknik Analisis Data}

Teknik analisis data dilakukan untuk mendapatkan perangkat pembelajaran layak digunakan dan berkualitas yang memenuhi kriteria kevalidan, kepraktisan, dan kefektifan.

\section{HASIL DAN PEMBAHASAN}

Pada bagian ini akan dipaparkan tahapantahapan pada pengembangan Modul matematika dengan menggunakan metode CPS yang meliputi tahapan pendefinisian, tahapan perancangan, tahapan pengembangan, dan tahapan penyebaran. Adapun tahapan-tahapannya dijabarkan sebagai berikut.

\section{Tahap Define (Pendefinisian)}

Tahap pendefinisian ini terdiri dari beberapa tahapan yaitu analisis materi, analisis siswa, analisis tujuan, dan spesifikasi produk. Adapun tahapannya akan dijabarkan sebagai berikut :

\section{a. Analisis Materi}

Pada tahap ini peneliti mengkaji materi kubus dan balok mulai dari Silabus sampai dengan RPP. Adapun silabusnya ialah sebagai berikut:

Tabel 1. Silabus Materi Kubus Dan Balok

\begin{tabular}{ll}
\hline \multicolumn{1}{c}{$\begin{array}{c}\text { Standar } \\
\text { Kompetensi }\end{array}$} & \multicolumn{1}{c}{ Kompetensi Dasar (KD) } \\
\hline $\begin{array}{l}\text { 5. Memahami } \\
\text { sifat-sifat } \\
\text { kubus dan } \\
\text { balok dan } \\
\text { bagian- } \\
\text { bagiannya } \\
\begin{array}{l}\text { serta } \\
\text { kubus dan bagiannya. } \\
\text { menentukan } \\
\text { ukurannya. }\end{array}\end{array}$ & $\begin{array}{l}\text { 5.2 Membuat jarring-jaring kubus } \\
\text { dan balok }\end{array}$ \\
\hline
\end{tabular}

Dengan adanya guru pamong yang memberikan krtik saran dapat memudahkan peneliti dalam menyusun RPP agar proses kegiatan belajar mengajar dapat efektif dan dapat menghasilkan proses pembelajaran yang maksimal. Dengan adanya analisis materi kubus dan balok ini peneliti dapat mengembangkan sebuah modul dengan menggunakan metode CPS yang membuat siswa dapat memecahkan masalah dan menghasilkan siswa yang berkreatif dalam memecahkan masalah yang diberikan.

\section{b. Analisis Siswa}

Pada tahap ini peneliti menganalisis kemampuan sifat siswa yang diteliti. Analisis diperlukan agar pembelajaran berlangsung dengan lancar dan efektif serta dijadikan gambaran untuk mempersiapkan bahan ajar yang berupa modul yang dibutuhkan. Berdasarkan hasil analisis peneliti memilih kelasVIII $_{\mathrm{B}}$ sebagai ujicoba terbatas yang terdiri dari 10 orang siswa dan $\mathrm{VIII}_{\mathrm{A}}$ SMPN 3 Mataram digunakan sebagai uji lapangan yang terdiri dari 31 orang siswa karena sebelumnya sudah belajar tentang materi kubus dan balok. Dengan adanya guru pamong yang cukup membantu peneliti dalam memilih kelas $\mathrm{VIII}_{\mathrm{A}}$ dan $\mathrm{VIII}_{\mathrm{B}}$ SMPN 3 Mataram sebagai uji lapangan karena selama proses pembelajaran yang telah diberikan oleh guru matematika di SMPN 3 Mataram belum pernah menggunakan bahan ajar yang berupa modul. Dengan adanya analisis siswa ini peneliti dapat mengembangkan bahan ajar yang berupa modul dengan metode CPS pada siswa kelas VIII $_{A}$ dan VIII ${ }_{B}$ SMPN 3 Mataram yang dapat menghasilkan siswa mampu memecahkan masalah yang diberikan.

\section{c. Analisis Tujuan}

Pada tahap ini peneliti dapat menetapkan tujuan dari pengembangan modul pembelajaran matematika yang akan dikembangkan di kelas VIII $_{\mathrm{a}}$ dan $\mathrm{VIII}_{\mathrm{b}}$. Pada penelitian ini pengembangan modul pembelajaran matematika dengan menggunakan metode CPS ini yakni dapat meningkatkan kemampuan dan kreatif belajar siswa dalam memecahkan masalah.

\section{d. Spesifikasi Produk}

Adapun spesifikasi produk yang akan disusun yakni produk hasil pengembangan ini berupa bahan ajar modul dengan menggunakan metode CPS.

\section{TahapDesign (Perancangan)}

Pada tahap awal rancangan awal modul ini terdapat beberapa bagian yaitu perancangan judul modul dan bagian-bagian yang terdapat pada modul ialah: 


\section{a. Perancangan Judul Modul}

Perancangan judul ditentukan dengan judul bab ditentukan oleh kompetensi dasar dan judul subbab ditentukan oleh indikator. Oleh karena itu, Modul yang disusun dalam penelitian terdiri dari 1 bab dengan 4 subbab dengan judul modul bangun ruang sisi datar dan subbab: (1) Pengertian kubus dan balok, (2) Mengenal unsur-unsur kubus dan balok, (3) Jaring-jaring kubus dan balok, dan (4) Luas permukaan kubus dan balok.

\section{b. Bagian-bagian Modul}

Pada modul terdapat beberapa bagian-bagian yaitu :

1) Halaman pembuka yaitu meliputi kata pengantar, daftar isi, peta konsep, deskripsi singkat, petunjuk penggunaan modul, standar kompetensi, dan kompetensi dasar.

2) Kegiatan siswa, pada kegiatan siswa ini terdapat tujuan pembelajaran dan indikator pembelajaran.

3) Latihan soal, pada latihan soal ini terdiri beberapa soal yang berkaitan dengan materi yaitu kubus dan balok, soal pada modul berbentuk soal essay.

4) Cover depan modul dan biografi penulis

5) Setelah format modul terbentuk akhirnya terbentuklah rancangan awal modul.

\section{Tahap Develop (Pengembangan)}

Tahap pengembangan ini terdiri dari beberapa tahapan yaitu validasi ahli, uji coba terbatas, uji coba lapangan. Adapun tahapannya akan dijabarkan sebagai berikut:

\section{a. Tahap Validasi Ahli}

Data diperoleh dari hasil validasi terhadap modul yang dinilai oleh 3 validator. Desain produk awal divalidasi terlebih dahulu sebelum dilakukan uji coba. Validasi desain dilakukan oleh tiga tenaga ahli yaitu ahli media oleh Bapak Sirajudin, M.Pd, ahli materi oleh Bapak Mahsup, M.Pd dan ahli bahasa oleh Bapak Drs. Akhmad H.Mus, M.Hum

1) Pengujian produk oleh ahli media ini dilakukan pada tanggal 27 Maret 2018 dengan menunjukkan dan menjelaskan tentang produk modul dengan metode menggunakan CPS kepada ahli media pembelajaran. Validator selaku Dosen Pendidikan MatematikadiUniversitas Muhammadiyah Mataram, Bapak Sirajudin,M.Pd. Menurut validator modul dengan metode CPS iniperlu diperbaiki yaitu dibagian latihan soal dengan menambahkan sebuah gambar balok yang dapat digunakan dalam bentuk sebuah soal cerita dalam kehidupan sehari atau gambar balok yang realistik. Hasil dari lembar validasi yang diisi validator sebagai berikut.Berdasarkan hasil angket ahli media di atas, maka diperoleh rataratadengan rumus sebagai berikut:

$$
\begin{aligned}
\bar{x} & =\frac{\sum_{\mathrm{i}=1}^{\mathrm{n}} \mathrm{A}_{\overline{1}}}{\mathrm{n}} \\
& =\frac{5 \times 5+3 \times 4}{8} \\
& =\frac{37}{8} \\
& =4,36
\end{aligned}
$$

Dapat dilihat nilai yang diberikan untuk kategori modulrata-rata tiap aspek mendapat penilaian yang baik. Dengan demiikian, berdasarkan kriteria kevalidan dapat dinyatakan bahwa modul tersebut sudah termasuk dalam kategori "sangat valid" dengan nilai rata-rata 4,36. Perbaikan modul dengan metode CPS ini juga memperhatikan pendapat dan saran yang diberikan oleh validator.

2) Pengujian produk oleh ahli materi ini dilakukan pada tanggal 27 Maret 2018 dengan menunjukkan dan menjelaskan tentang produk modul dengan metode CPS kepada ahli materi pembelajaran. Validator selaku Dosen Pendidikan Matematika Bapak Mahsup, M.Pd memberikan penilaian terhadap modul dengan metode CPS ini pada lembarvalidasi ahli materi. Saran beliau ditambahkan pendahuluan latihan soal pada akhir materi pada modul. Hasil dari lembar validasi yang diisi validator sebagai berikut :

Berdasarkan hasil angket ahli media di atas, maka diperoleh rata-ratadenganrumus sebagai berikut :

$$
\begin{aligned}
\bar{x} & =\frac{\sum_{i=1}^{n} A_{\bar{l}}}{n} \\
& =\frac{2 \times 2+3 \times 3+5 \times 5}{10} \\
= & \frac{38}{10} \\
& =3,8
\end{aligned}
$$

Dapat dilihat nilai yang diberikan untuk kategori modulrata-rata tiap aspek mendapat penlaian yang baik. Dengan demiikian, berdasarkan kriteria kevalidan dapat dinyatakan bahwa modul tersebut sudah termasuk dalam kategori "Valid" karena nilai rata-rata dari aspek penilaian yaitu 3,8. Perbaikan modul dengan metode CPS ini juga memperhatikan pendapat dan saran yang diberikan oleh validator. 
3) Pengujian produk oleh ahli bahasa ini dilakukan pada tanggal 29 maret 2018 dengan menunjukkan dan menjelaskan tentang produk modus dengan metode CPS kepada ahli bahasa pembelajaran. Validator selaku Dosen Pendidikan Bahasa IndonesiaBapak Drs. Akhmad H. Mus, M. Hum memberikan penilaian terhadap modus dengan metode CPSini pada lembarvalidasi ahli bahasa. Saran beliau lanjutkan cara belajar dan menganalisis masalah agar menjadi peneliti yang baik. Hasil dari lembar validasi yang diisi validator sebagai berikut: Berdasarkan hasil angket ahli bahasa di atas, maka diperoleh rata-rata dengan rumus sebagai berikut:

$$
\begin{aligned}
\bar{x}= & \frac{\sum_{i=1}^{n} A_{\bar{l}}}{n} \\
= & \frac{2 \times 3+3 \times 4}{5} \\
& =\frac{18}{5} \\
& =3,6
\end{aligned}
$$

Dapat dilihat nilai yang diberikan untuk kategori modulrata-rata tiap aspek mendapat penlaian yang baik. Dengan demiikian, berdasarkan kriteria kevalidan dapat dinyatakan bahwa modul tersebut sudah termasuk dalam kategori 'Valid" karena nilai rata-rata dari aspek penilaian yaitu 3,6. Perbaikan modul dengan metode CPS ini juga memperhatikan pendapat dan saran yang diberikan oleh validator.

Berdasarkan hasil validasi dari 3 dosen ahli tersebut maka diperolehrata-rata validasi total dengan rumus sebagai berikut:

$$
\begin{aligned}
\bar{x} & =\frac{\sum_{i=1}^{n} A_{\bar{l}}}{n} \\
& =\frac{4,36+3,8+3,6}{3} \\
& =\frac{11,76}{3} \\
& =3,92
\end{aligned}
$$

Nilai tersebut masuk dalam kategori "Valid".Validasi ini dilakukan untuk mengetahui kelemahan dan kelebihan produk yang dikembangkan.

\section{b. TahapUji Coba Terbatas Produk}

Sebelum diujicobakan kelapangan secara langsung, produk diujicoba terbataskan terlebih dahulu dengan memilih 10 siswa yang dapat mewakili populasi siswa kelas VIII $\mathrm{b}_{\mathrm{b}}$ SMP Negeri 3Mataram untuk mengetahui kemudahan, kemenarikan dan kemanfaatan produk tersebut.
Namun, dengan adanya guru matematika sebagai wakil dari siswanya yang mengetahui kemampuan berpikir dari siswanya bersedia memilih sendiri jenis soal dan pembahasan yang pantas dan layak untuk siswanya.

Berdasarkan respon siswa di atas terhadap produk modul pembelajaran dengan menggunakan metode CPS maka diperoleh persentase dengan rumus sebagaiberikut:

PRS $=\frac{A}{B} \times 100 \%$

$$
=\frac{10}{10} \times 100 \%
$$

$=100 \%$

Menganalisis hasil uji coba terbatas untuk melihat kekurangan dan kelebihan modul yang digunakan. Tujuan hasil uji cobaterbatas ini adalah untuk mengetahui kelebihan dan kekurangan produk hasil pengembangan. Berikut ini hasil evaluasi uji coba terbatas. Nilai ketuntasan belajar klasikal siswa dengan rumus sebagai berikut

$$
\begin{gathered}
\text { Ketuntasan Klasikal }=\frac{A}{B} \times 100 \% \\
=\frac{8}{10} \times 100 \% \\
=80 \%
\end{gathered}
$$

Hasil tes evaluasi uji coba terbatas di atas dapat dilihat bahwa sudah banyak siswa yang memenuhi KKM yang ditentukan oleh Sekolah SMPN 3 Mataram yaitu (75). Namun, ada beberapa hal pada modul yang perlu dilakukan revisi untuk memudahkan siswa dalam mengerjakan dan memahami modul.

\section{c. Revisi Hasil Uji Coba Terbatas}

Setelah dilakukan pengujian produk secara terbatas, selanjutnya produk perlu direvisi kembali untuk memperbaiki kelemahankelemahan yang masih ada.Revisi produk dilakukan untuk menyempurnakan kembali produk yang telah dikembangkan dan disesuaikan dengan kondisi nyata di lapangan berdasarkan hasil uji coba produk.

\section{d. Tahap Uji CobaLapangan}

Setelah pengujian uji coba terbatas produk berhasil, selanjutnya produk diujicobakan pemakaiannya pada uji lapangan.Uji lapangan ini dilakukakan kepada satu kelas sampel, yaitu kelas VIII $_{\mathrm{A}}$ dengan jumlah siswa 31 orang dengan berbagai karakteristik (tingkat kepandaian, jenis kelamin, kemajuan belajar dan sebagainya).Prosedur pelaksanaannya sebagai berikut.

1) Menjelaskan bahwa modul ini berada pada tahap uji coba dan memerlukan 
umpanbalik untuk menyempurnakannya. Uji coba modul inimenggunakan metode CPS.

2) Melaksanakan

pembelajarandenganmenggunakan modul yangdikembangkan.

3) Memberikan soal tes evaluasi

4) Membagikan angket atau kuesioner dan meminta siswa mengisinya. Kuesioner yang dibagikan yaitu untuk mengetahui tingkat kemenarikan, kemudahan, kemanfaatan dan keefektifan modul yang dikembangkan dengan metode CPS sebagai bahan ajar dalam pembelajaran. Berikut angket respon siswa.

Berdasarkan respon siswa di atas terhadap produk modul pembelajaran dengan menggunakan metode CPS maka diperoleh persentase dengan rumus sebagai berikut :

$$
\begin{aligned}
\text { PRS } & =\frac{A}{B} \times 100 \% \\
& =\frac{31}{31} \times 100 \%=100 \%
\end{aligned}
$$

5) Menganalisis hasil uji lapangan untuk melihat kekurangan dan kelebihan modul yang digunakan. Tujuan hasil uji coba lapangan ini adalah untuk mengetahui kelebihan dan kekurangan produk hasil pengembangan. Berikut ini hasil evaluasi uji lapangan setelah menggunakan revisi produk. Nilai ketuntasan belajar klasikal siswa dengan rumus sebagai berikut :

$$
\begin{aligned}
\text { Ketuntasan Klasikal } & =\frac{A}{B} \times 100 \% \\
& =\frac{31}{31} \times 100 \% \\
& =100 \%
\end{aligned}
$$

Penelitian ini bertujuan untuk menghasilkan modul sebagai media pembelajaran matematika pada materi kubus dan balok. Adapun langkah-langkah pengembangan berdasarkan model pengembangan 3-D. Model 3-D ini terdiri dari 3 tahap pengembangan, yaitu define (pendefinisian), design (perancangan),dan develop (pengembangan). Adapun produk yang dihasilkan adalah modul pembelajaran matematika pada materi kubus dan balok.

Layak atau tidaknya modul pembelajaran ini dapat diketahui dengan melakukan validasi ahli kebeberapa validator, baik ahli media, ahli bahasa, maupun ahli materi dan diujicobakan kepada siswa kelas VIII SMPN 3 Mataram. Validasi ahli media oleh bapak Sirajudin, M.Pd, ahli bahasa oleh bapak Drs. Akhmad H. Mus, M. Hum, dan ahli materi oleh bapak Mahsup, M.Pd dosen FKIP Ummat.

Hasil validasi ahli media menunjukan rata-rata penilaian untuk semua butir pertanyaan adalah 4,36 dan termasuk dalam kategori sangat valid. Walaupun telah dikategorikan sangat valid dan sudah layak digunakan, tetapi validator memberikan kesimpulan terhadap penilaian dari segi media bahwa modul disarankan perlu dilakukan revisi dibeberapa indikator. Hasil validasi ahli materi menunjukan rata-rata penilaian untuk semua butir pertanyaan adalah 3,8 dan termasuk dalam kategori valid. Walaupun telah dikategorikan valid dan sudah layak digunakan, tetapi validator memberikan kesimpulan terhadap penilaian dari segi materi bahwa modul disarankan untuk menambahkan latihan soal. Validasi ahli bahasa menunjukan rata-rata penilaian untuk semua butir pertanyaan adalah 3,6 dan termasuk dalam kategori valid. Walaupun telah dikategorikan valid dan sudah layak digunakan, tetapi validator memberikan kesimpulan terhadap penilaian dari segi bahasa bahwa disarankan untuk memperhatikan kembali susunan-susunan kalimat yang digunakan di dalam modul tersebut dan sudah layak untuk diujicobakan.

Uji coba modul pembelajaran dilakukan pada 10 orang siswa kelas VIII ${ }_{b}$ dan 31 orang siswa kelas VIII $_{\mathrm{a}}$ SMPN 3 Mataram. Pemilihan kelas ditentukan oleh guru pamong disekolah karena dia cukup mengetahui kemampuan dan karakter siswanya di masing-masing kelas. Uji coba dilakukan pada 10 orang siswa kelas VIII $_{b}$ ini ialah dimaksud dengan uji coba terbatas, uji coba terbatas ini dilakukan untuk mengetahui kelebihan dan kekurangan dan kepraktisan produk yang dikembangkan. Adapun nilai rata-rata dari hasil angket respon siswa yaitu 4,47 yang dikategorikan sangat praktis. Setelah melaksanakan uji coba terbatas maka peneliti melakukan uji coba lapangan yang terdiri dari 31 orang siswa kelas $\mathrm{VIII}_{a}$, uji coba lapangan ini dilakukan untuk mengetahui tingkat kemenarikan, kemudahan, kemanfaatan dan keefektifan modul yang dikembangkan dengan metode CPS. Adapun nilai rata-rata dari hasil angket respon siswa yaitu 4,84 yang dikategorikan sangat efektif. Dapat disimpulkan bahwa produk yang dikembangkan sudah memenuhi kategori valid, praktis, dan efektif.

\section{SIMPULAN DAN SARAN}

Berdasarkan pembahasan hasil penelitian dapat disimpulkan bahwa modul yang dikembangkan dengan metode CPS sudah termasuk dalam kategori valid, praktis, efektif dan sudah dapat disebar luaskan khususnya di kelas VIII SMP Negeri 3 Mataram yang belum menggunakan modul pembelajaran matematika dengan metode CPS pada pokok bahasan bangun ruang tersebut.

1. Bahan ajar pembelajaran dikatakan valid berdasarkan penilaian validator.

Dari hasil validasi oleh ahli diperoleh bahan pembelajaran yang sesuai dengankriteria valid.Rata-ratapenilaian validator yaitu Modul 
berdasarkan ahli materi 3,8 (valid), modul berdasarkan ahli media 4,36 (sangat valid), dan modul berdasarkan ahli bahasa 3,6 (valid). Berdasarkan hasil validasi ahli ini bahwa modul pembelajaran yang dihasilkan sudah layak digunakan untuk uji coba dengan revisi. Adapun revisi dari ahli materi yaitu menambahkan contoh soal di modul, revisi dari ahli media yaitu menambahkan gambar di contoh soal yang berkaitan dengan kehidupan nyata sesuai dengan soal dibagian latihan soal.

2. Berdasarkan uji coba bahan ajar pembelajaran dengan menggunakan metode CPS yang dihasilkan modul pembelajaran tersebut dinyatakan "Sangat Praktis" yaitu berdasarkan penilaian angket respon siswa dengan nilai rata-rata 4,84. Modul tersebut dinyatakan sangat praktis. Berdasarkan hasil uji coba ini menunjukan bahwa modul pembelajaran dengan menggunakan metode CPS sudah cukup bagus untuk siswa. Jadi, dapat disimpulkan bahwa hasil uji coba terbatas modul pembelajaran ini sudah cukup bagus untuk diterapkan kepada siswa dan menuju kepada tahap selanjutnya yaitu uji lapangan.

3. Berdasarkan uji lapangan bahan ajar pembelajaran dengan menggunakan metode CPS yang dihasilkan modul pembelajaran tersebut dinyatakan "efektik" yaitu berdasarkan prestasi belajar siswa pada pembelajaran matematika materi bangun ruang telah mencapai ketuntasan klasikal maupun individual yang diinginkan dengan nilai rata-rata 93,1 dapat dilihat bahwa adanya peningkatan dari sebelumnya nilai rata-rata 81,8. Jadi, dapat disimpulkan bahwa modul pembelajaran matematika ini sudah memenuhi valid, praktis, dan efektif sehingga dapat dijadikan sebagai bahan ajar pembelajaran matematika pada materi bangun ruang.

Dalam belajar hendaknya siswa memiliki motivasi untuk meningkatkan kemampuan pemecahan masalah dengan lebih aktif dan lebih banyak berlatih soal-soal mengenai sistem persamaan linear dua variabel serta mendalami materi dari segi konseptual agar siswa tidak kesulitan bila menghadapi soal yang berbeda dengan contoh yang diberikan oleh guru.

Adapun saran yang dapat diberikan penulis diantaranya yaitu:

1. Bahan ajar modul dengan metode CPSini sudah diuji kelayakannya dengan uji kevalidan, kepraktisan dan keefektifan. Modul pembelajaran ini juga masih memiliki kekurangan seperti kurangnya indikator yang dibahas di dalam modul ini dan disarankan untuk peneliti selanjutnya dapat melengkapi indikator-indikator atau hal lainnya yang masih kurang atau yang belum ada di dalam modul tersebut. Selain itu penurunan konsep dalam modul belum menggunakan prinsip konstruktivisme, dimana konsep dibangun berdasarkan pengalaman-pengalaman siswa.

2. Instrumen yang digunakan untuk menentukan kevalidan, kepraktisan dan keefektifan hanya terbatas lembar validasi ahli, lembar respon siswa dan tes hasil belajar siswa, sehingga untuk peneliti selanjutnya dapat mengkaji lebih dalam untuk menggunakan instrumen yang lebih lengkap dengan menambahkan instrumen lain seperti lembar observasi aktivitas siswa, lembar keterlaksanaan pembelajaran, serta menggunakan lembar untuk memberi jawaban terbuka untuk masukan instrumen yang lebih baik.

3. Hendaknya penelitian ini diajukan sebagai acuan untuk meneliti di tempat dan pada subjek lain dengan catatan kekurangankekurangan yang ada dalampenelitian ini hendaknya direfleksikan untuk diperbaiki.

\section{UCAPAN TERIMA KASIH}

Ucapan terima kasih kepada semua pihak yang telah membantu dalam proses penelitian ini, terutama kepada Kepala Sekolah, Bapak dan Ibu guru SMPN 3 Mataram yang telah mengijinkan melakukan penelitian di SMP tersebut.

\section{REFERENSI}

Aqib, Zainal, dkk. (2011). Penelitian Tindakan Kelas untuk Guru SD, SLB, dan TK. Bandung. Yrama Widya.

Dwi Ivayana Sari, dkk. (2016).Efektivitas Model Pembelajaran Creative ProblemSolving(CPS) Pada Materi Lingkaran Di Kelas VIII MtsNurul Huda. Jurnal Apotema, 2(2), 76-85.

Eko Putro Widoyoko. (2009). Evaluasi Program Pembelajaran: PanduanPraktisBagi Pendidik dan Calon Pendidik. Yogyakarta: Pustaka Pelajar.

Majid. (2013). Strategi Pembelajaran. Bandung: PT Remaja Rosdakarya.

Mahardika, I Ketut; Maryani; Murti, Selly Candra Citra. (2013). Penggunaan Model Pembelajaran Creative Problem Solving Disertai LKS Kartun Fisika Pada Pembelajaran Fisika Di SMP. Jurnal Pembelajaran Fisika, 1(2), 231-237.

Moh. Agung Arif Z, Abdillah. (2018). Pengembangan Modul Belajar Mandiri LaTeX Beamer Sebagai Alternatif Media Presentasi Mahasiswa Program Studi Pendidikan Matematika. Jurnal Teori dan Aplikasi Matematika, 2(2), 138-143.

Muhamad Syazali. (2015). Pengaruh Model Pembelajaran Creative Problem Solving Berbantuan Media Maple 11 Terhadap Kemampuan Pemecahan Masalah Matematis. Al Jabar: Jurnal Pendidikan Matematika, 6(1), 91-98. 